\title{
Pleistocene Stratigraphy of the Breckland
}

\section{By T. T. Paterson, University Museum of Archæology and Ethnology, Cambridge}

\begin{abstract}
A $\mathrm{T}$ the British Association meeting last year, during an excursion by the Geological Section to the Breckland, a sequence of the Pleistocene deposits there was demonstrated. Many requests for information have indicated that a short review of the stratigraphy and prehistory, prior to publication of a full memoir on that region, would be useful to geologists and prehistorians interested in the Pleistocene in England.
\end{abstract}

Moreover, they are coloured brownish by reason of loam and clay derived from an earlier interglacial deposit. The Middle and Upper have previously been confused and named the Upper Chalky Boulder Clay.

The Lower Boulder Clay $(B)$ is only found on the slopes of shallow ancient valley forms and on higher ground, having been removed principally by a long period of erosion $(C)$ which succeeded the ice advance and was related to a period of uplift. This must have

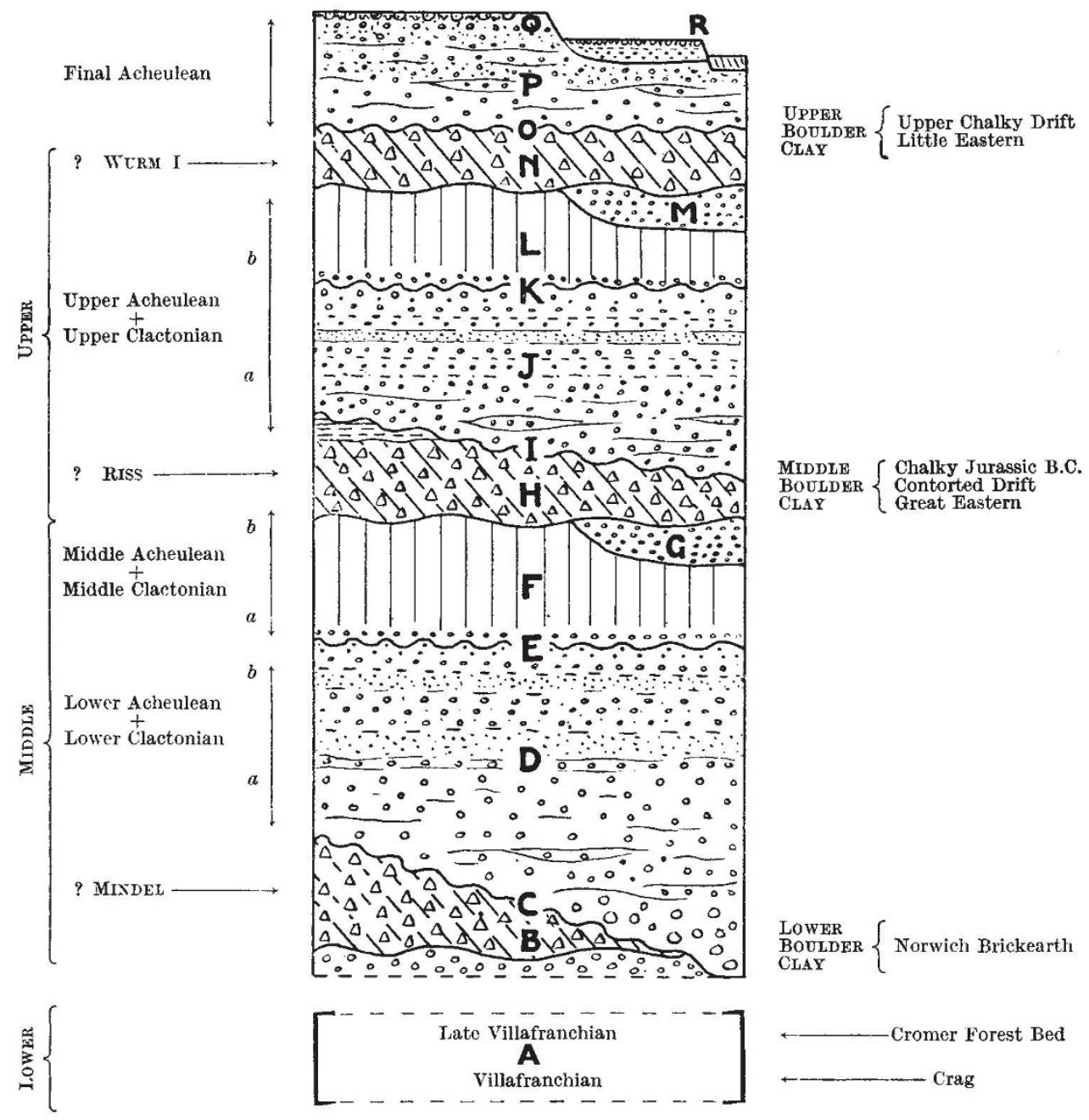

There are three boulder clays, ealled here the Lower, Middle and Upper. The Lower, hitherto called the Great Chalky Boulder Clay, is distinguished by its erratics from Scotland, Yorkshire and Scandinavia, as well as Jurassic and Kimmeridgic material ; whereas the Middle and Upper are very much alike, carrying a great quantity of English, especially Triassic, erratics and none from very far parts. been quite extensive since valleys several hundred feet deep were then cut out, and it is the period when the major features of the present landscape were decided. A great period of aggradation filled these valleys with gravels $(D)$ up to about the level of our present river system. A warm fauna roamed the land surface so established. A period of increased rain deposition led to some slight erosion $(E)$ and 
subsequent formation of a loam $\left(F^{\prime}\right)$. Another period of slight aggradation with a temperate fauna $(G)$ was followed by advance of an English glacier $(H)$, when the land was depressed some 150 feet.

The sequence of the first interglacial was repeated, but during a shorter second interglacial. Uplift was followed by erosion (I), valleys being excavated, generally along previously established drainage lines though some deflections occurred. Aggradation $(J)$ was continued into a temperate period. A colder oscillation $(K)$ was followed by temperate conditions, and deposition of a loam $(L)$. A period of slight erosion $(M)$ cut into the loam, and the Upper Boulder Clay was then deposited as a skin over the greater part of the Breckland, though not in the hills to the south.

This boulder clay and its associated gravels form an Upper Terrace dissected by an erosion phase $(O)$ which cut out the present radial drainage of the Breckland. A Middle terrace was formed of well bedded gravels $(P)$. Towards the upper part a cold fauna is succeeded by a bed $(Q)$ showing the effects of sludging under severe cold conditions. A period of erosion and aggradation forms a late Low Terrace $(R)$.

Because of its general lithological character and physiographic configuration the Lower Boulder Clay (the Great Chalky Boulder Clay of West Norfolk and Suffolk) is equated with the Norwich Brickearth. The Middle Boulder Clay is equated with the Great Chalky Boulder Clay (the Great Eastern Drift) of East Norfolk and Suffolk. The Upper Boulder Clay is equated with the 'Upper Chalky Boulder Clay and Little Eastern Drift'. A more widespread correlation is not possible here, but will appear in the full memoir, which, it is hoped, will be published later this year.

At several horizons palæolithic industries have been discovered. The Acheulean is divisible into Lower a and $b$, Middle $a$ and $b$, Upper $a$ and $b$, and Final. The Clactonian can similarly be subdivided, into Lower $a$ and $b$, Middle $a$ and $b$, and Upper $a$ and $b$. In general, it may be said that :

The Lower Acheul occurs during the early part of the Lower-Middle Interglacial prior to phase $(E)$ and is characterized by free flaking, no controlled secondary work, no fine retouch, thickness, cortex remains, irregular outline and dominant pyriform shapes.

The Middle Acheul occurs during the later part of the Lower-Middle Interglacial and is characterized by the presence of much controlled secondary working, some retouch (more in Middle $b$ ), and linguate and ovate forms dominant. (In southern England the pseudo-Micoquian is dominant in Middle b.)

The Upper Acheul appears in the Middle-Upper Interglacial and is characterized by much controlled secondary working, fine retouch including controlled step retouch, thinness, no cortex, very fine and regular outlines (twisted forms common), small foliates, pointed ovates and straight-sided pyriform types dominant.

The Final Acheul appears in the post-Upper Boulder Clay aggradation gravels with the same general characters as the Upper Acheul, somewhat finer if anything, but the 'proto-celt' and the triangular forms appear.

The Lower Clacton occurs in the same period as Lower Acheul, with massive flakes, generally much cortex remaining, no controlled secondary retouch, no specifically prepared forms, and the cores coarsely biconvex and serrate, with no flat-bottomed forms.

The Middle Clacton occurs in the same period as the Middle Acheul and has thinner flakes, cortex wholly removed, controlled secondary working, some retouch, specifically prepared forms, points and suchlike, proto-Levallois and Levallois cores, biconvex, serrate and flat-bottomed.

The Upper Clacton occurs in the same period as the Upper Acheul. Apparently the Upper Acheul has absorbed some northern Upper Clacton* elements and the only dominantly Clacton industry is of southern faciest, direct descendant of a Middle Clacton $b$ of the Thames. The flakes are equally sideand end-types from biconvex and flat-bottomed cores, and of specific shapes. There are no pseudo- or proto-Levallois flakes or cores. The flakes are strong with median ridges instead of flake scars. There is no secondary working, but finely developed scaling retouch. Outlines are regular.

Faceted, possibly Levallois, flakes are occasionally found but no industry has so far been unearthed.

On broad palæontological and stratigraphical grounds, the Pleistocene is divided into Lower, Middle and Upper. This division corresponds to three cycles of deposition, the first being less marked than the others. Both Middle and Upper begin with extensive land movement. The Lower is so named because of the Villafranchian and late Villafranchian character of the fauna.

" "Tayacian" stem of the Clacton.

t "Mousterian" stem of the Clacton.

\section{British Empire Telegraph Communications}

$\mathrm{D}$ URING the last ten years very rapid progress has been made in both telegraph and radio communication throughout the British Empire. In a paper by K. L. Wood recently read to the Institution of Electrical Engineers, the engineering aspect of the whole of this world-wide communication is considered. A short history of progress in cable telegraphy is given, but full explanations are given of novel technical methods. Methods of operating radio are also described, and reference is made to the effects of varying cosmic conditions on radio signals.
September 29, 1929, was a notable date in world communication, as on that date all the telegraph communications of the British Empire were, by Act of Parliament, placed in the hands of a single operating company. At the same time an Imperial Communications Advisory Committee was set up, the members of which were nominated by the British and Dominion Governments. A long list is given of the main companies taken over by the operating company. In addition, the ship and aireraft services were taken over as well as various small radio 